\title{
Treatment of Liquid Oil Spill by Untreated and Treated Aswanly Clay from Egypt
}

\author{
${ }^{* 1}$ SAYED, S A; EL SAYED, A S; *EL KAREISH, S M; *ZAYED, A M \\ Dept. of Chemistry, Faculy of Science, Helwan University, Ain Hetwan, P.No.11795, Cairo, Egypt. \\ Researth Center, Misr Potroleum Company, Ghamra, Cairo, Egypt. \\ * Esyptirm General Petroleum Corporation. Quality Control Dept. New Maadi, P.No. 11742, Cairo, Esypt
}

\begin{abstract}
ABSTRA C'T: The aim of this work is to use cheap, available and recyclable sorbents for oil spill clean - up. a - $\mathrm{SiO}_{3}$.Quart., $\mathrm{Na}_{2} \mathrm{Si}_{2} \mathrm{O}_{3}(\mathrm{OH})_{4}, \mathrm{CaCO}_{3}, \mathrm{MgCO}_{3}, \mathrm{BaCO}_{3}, \mathrm{CaO}, \mathrm{MgO}$, and $\mathrm{Fe}_{2} \mathrm{O}_{3}$ are used individually or mixed with Aswanly clay to identify the sorption activity of these materials and to show the effect of incorporation of these materials into the Aswanly clay. Results were $6.3,75,100,93,95,75,92,100,80,98,90,71,90$ and $97 \%$ on using $1.0 \mathrm{~g}$ a $-\mathrm{SiO}_{2}-\mathrm{Quart}_{4}, 0.9 \mathrm{~g} \mathrm{Na}_{2} \mathrm{Si}_{2} \mathrm{O}_{5}(\mathrm{OH})_{4}, 0.07 \mathrm{~g} \mathrm{CaCO}_{3}, 0.05 \mathrm{~g} \mathrm{MgCO}_{3}, 0.08 \mathrm{~g} \mathrm{BaCO}, 0.05 \mathrm{~g} \mathrm{CaO}, 0.1 \mathrm{~g}$ $\mathrm{MgO}$, and $0.08 \mathrm{~g} \mathrm{Fe}_{2} \mathrm{O}_{3}, 0.1 \mathrm{~g}$ clay mixlure of $50 \% \mathrm{CaCO}_{3}, 0.1 \mathrm{~g}$ clay mixture of $10 \% \mathrm{MgCO}, 0.1 \mathrm{~g}$ clay mixture of $50 \% \mathrm{Ba}(\mathrm{O}, 0.1 \mathrm{~g}$ clay mixture of $50 \% \mathrm{CaO}, 0.1 \mathrm{~g}$ clay mixture of $10 \% \mathrm{MgO}$, and $0.1 \mathrm{~g}$ clay mixture of $50 \%$ $\mathrm{Fe}_{2} \mathrm{O}_{3}$ respectively, to remove $14.07 \mathrm{mg}$ crude oil, below which mechanical means for removing crude oil from oi contaminated water becomes less more effective, from oil contaminated water of volume $25 \mathrm{ml}$ from oil contaminated water at $\mathrm{pH} 6$ and temperature $30^{\circ} \mathrm{C}$. All of these materials were treated by naphtha, a petroleum product of boiling range $30^{\prime \prime} \mathrm{C}-165^{\prime \prime} \mathrm{C}$, to remove sorbed crude oil from its surface for further reuse and contaminated naphtha are processed to be distilled for reuse. Characteristics of crude oil and Aswanly clay were investigated by FTIR, $x$ - Ray Fluorescence, $X$ - Ray Diffraction, pour point and centrifuge instruments. Determination of amount of crude oil in water was done by extraction the crude oil with 10 ml $n$-hexane and measuring absorbance by UV - VIS. Spectrometer. (a) ASEM
\end{abstract}

As the Crude oil is a very complex mixture of many different chemicals, consequenty the effects of an oil spill on the marine environment is dependent on the exact nature and quantity of the oil spilled, as well as such other factors as the prevailing weather conditions and the ecological characteristics of the affected region (Berridge, 1968; Piwoni and Banerjee , 19899 and William and Morse, 1979). According to the complex nature of oils, they do not behave as the same in the environment. Some constituents are noted for their tendency to vaporize while others cleatly prefer to bind to solids; some oil hydrocarbons are extremely unreactive while other interacts with light, so they have different toxicological effects on the aquatic life and hence on human being (Bo, 1987;1 Ralph, 1955; Rene, 1983).

Gulf of Suez mixture crude oil is used for the purpose of our study since it represents about $60 \%$ of the mass production of Egyptian crude oil, which, is transferred directly to oil refining companies or for exportation along Suez Canal. It is a mixture of crude oils produced from nearly 33 fields located at the Red Sea area. Analyses figures for the tested crude oil according to the institute of petroleum (IP) test methods are listed in Table 1 (IP, 2001).

Table 1. Physical properties of Gulf Suez mixture crude oil

\begin{tabular}{|c|c|c|c|}
\hline \multicolumn{2}{|c|}{ Parameters } & \multirow{2}{*}{$\frac{\text { Test method }}{\text { IP' } 160}$} & \multirow{2}{*}{$\begin{array}{l}\text { Results } \\
0.8544\end{array}$} \\
\hline Density at $15^{\circ} \mathrm{C}$ & $\mathrm{kg} / \mathrm{l}$ & & \\
\hline Sediment & $\%$ mass & IP 53 & NIL \\
\hline Water & $\%$ Vol. & II' 74 & 0.35 \\
\hline Salt & g mass & $1 P 77$ & 0.004 \\
\hline Sulphur & $\%$ mass & If 336 & 1.42 \\
\hline Pour point & "C & IP 15 & -3 \\
\hline \multicolumn{2}{|c|}{ Viscosity Redweed at $37.8^{\circ} \mathrm{C}$ Sec. } & $\mathbb{N P} 212$ & 31 \\
\hline Iron & $\mu \mathrm{g} / \mathrm{ml}$ & & 130 \\
\hline Vanadium & $\mu \mathrm{g} / \mathrm{ml}$ & Inductive Coupled Plasmn & 70 \\
\hline Chromitum & $\mu \mathrm{g} / \mathrm{ml}$ & & 30 \\
\hline
\end{tabular}

Figure I shows the I.R spectra (FT/IR-410 Spectrometer, Jasco) of the tested petroleum crude oil. Inspection of these spectra reveals the presence of the following two peaks at wave no. $2923 \mathrm{~cm}^{-1}$ and $2853 \mathrm{~cm}^{-1}$ represent $-\mathrm{CH}_{3}$ and $-\mathrm{CH}_{2}-$ stretching frequencies; two peaks at wave no $1462 \mathrm{~cm}^{-1}$ and

* Corresponding author 
$1377 \mathrm{~cm}^{-1}$ represent $-\mathrm{CH}_{3}$ and $-\mathrm{CH}_{2}-$ bending frequencies and peak at $722 \mathrm{~cm}^{-1}$ for aliphatic hydrocarbons of chains containing carbon atoms equal or greater than seven. These data indicate that the crude oil has a paraffinic nature of the following physical properties (Wauquier et al., 1995).

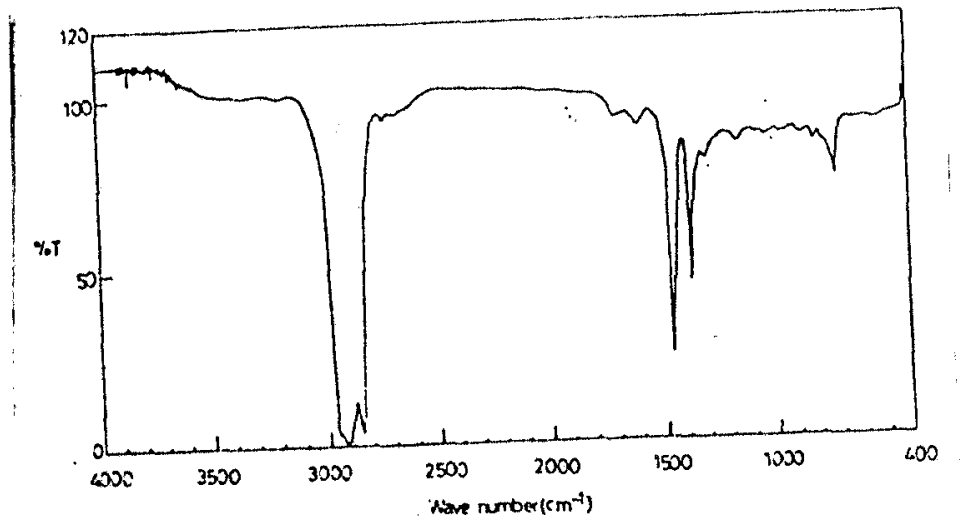

Fig.1. I.R spectra (HT/IR-410 Spectroneter, Jasco) of the tested petroleum crude oil

Bryk and Yakovenco, (1987), showed that treating water with oil spills necessitated the use of an oleophilic adsorbent, which must have magnetic properties to permit ready collection. Fuel oil and clay with a high content of iron oxides underwent thermal oxidation destruction to produce a uniform, black, powdery, porous hydrophobic product whose capacity for petroleum adsorption is $3.5-4 \mathrm{~g} / \mathrm{g}$. The iron oxides were reduced to ferromagnetic forms, and the magnetic susceptibility of the thermally treated composition reached a maximum after 90 minutes of treatment at $360^{\circ} \mathrm{C}$. Complete restoration of the magnetic and sorption propertics of the adsorbent is achievable at $350^{\circ} \mathrm{C}$ for 2 hours.

James and Shan, 1996 removed spilled oil from shorelines or from the surface of a body of water by adding to the surface a mixture of fine hydrophilic mineral solids dispersed in an aqueous liquid that interacts with the oil to form buoyant mineral finesoil floccules. These floccules reduce the tendency of the oil to adhere to solid surfaces or to recoalesce, thus facilitating dispersion and removal of the oil.

A chemical composition and method for treating oilcontaminated wastewater and more particularly, waste water in the form of oily emulsions that may also contain dissolved metal ions, and/or metal solids, to sorb (adsorb and/or absorb) the contaminants between and within platelets of sodium bentonite clay particles, and calcium bentonite clay particles, and the contaminants are encapsulated or trapped in a mixture of calcium bentonite platelets and sodium bentonite platelets that are flocculated by a flocculent, such as cationic polymer, so that leaching of contaminants into the wastewater, or subsequently into a liquid portion of a landfill is unexpectedly reduced (Laura 1997).

Among many different clays spread all over our country, Egypt (Abou El Naga et al., 1998), Aswanly clay (which is mechanically grounded to 160 -micron mesh size) is selected for the purpose of treatment of oil spills and industrial wastewater, because of its wide use in the ceramic industry. X-ray florescence analysis (Sequential XRF; Applied Research Laboratories, ARL 9400) by fusing the Aswanly clay with potassium tetra-borate as diluent is given in details in Table 2; in order to identify other impurities present within the clay structure, which may affect the uptake of oils.

$X$-Ray diffraction (Phillips $X$ - Ray diffraction, PW 1010) with scanning limited from $20=6$ to $20=62$ on the copper target with nickel filter of the untreated clay is presented in Table 2 . It is obvious that the main components are $\alpha-\mathrm{SiO}_{2}$-Quart $z, \mathrm{Al}_{2} \mathrm{Si}_{2} \mathrm{O}_{5}(\mathrm{OH})$ 4. $\mathrm{FeO}, \gamma-\mathrm{Fe}_{2} \mathrm{SiO}_{4}, \mathrm{Fe}_{3} \mathrm{Al}_{2}\left(\mathrm{SiO}_{4}\right)_{3}$ and $\mathrm{Fc}_{2} \mathrm{O}_{3}$ which are designated by capital letters $A, B, C, D, E, F$ respectivly Nelson-Smith, 1973 and Wanqueir, 1995). The observable signals of the infrared spectra of the applied material - untreated clay is given in Table 3.

Aswanly clay was used formerly to sorb crud oil from oil-contaminated water in a previous work Sayed and Abu Bakr, 2002. Uptake efficiency percent were $65 \%$ on using $0.1 \mathrm{~g}$ untreated Aswanly clay, $89 \%$ on using thermally treated Aswanly clay at $1200^{\circ} \mathrm{C}$ and $90 \%$ on using chemically treated Aswanly clay with hot concentrated phosphoric acid. 
Table 2. X-ray florescence analyses of the Aswanly clay'

Table 3. I.R signals and assigmments of the used materials

\begin{tabular}{|c|c|c|c|c|c|c|c|}
\hline Oxide & Mass $\%$ & Tlement & Mass $\%$ & Oxicle & Mass $\%$ & Blement & Mass $\%$ \\
\hline $\mathrm{SiO}_{2}$ & 58.5 & $\mathrm{Si}$ & 27.35 & $\mathrm{HIO}_{2}$ & 0.0773 & IIf & 0.0656 \\
\hline $\mathrm{Al}_{2} \mathrm{O}_{2}$ & 27.58 & $\mathrm{Al}$ & 14.6 & $\mathrm{MnO}$ & 0.0690 & $\mathrm{Mn}$ & 0.0534 \\
\hline $\mathrm{FeO}_{3}$ & 7.76 & $\mathrm{Fe}$ & 5.43 & $\mathrm{~V}_{2} \mathrm{O}_{3}$ & 0.0347 & $\mathrm{~V}$ & 0.0194 \\
\hline $\mathrm{IiO}_{2}$ & 1.75 & $\mathrm{Ti}$ & 1.05 & $\mathrm{TrO}$ & 0.0322 & $\mathrm{Zr}$ & 0.0238 \\
\hline $\mathrm{K} . \mathrm{O}$ & 1.03 & $K$ & 0.859 & 5 & 0.0297 & $S$ & 0.0297 \\
\hline 60 & 0.916 & Ca & 0.655 & $\mathrm{Cr}_{2} \mathrm{O}_{1}$ & 0.0247 & $\mathrm{Cr}$ & 0.0185 \\
\hline $\mathrm{Na}, \mathrm{O}$ & 0.867 & $\mathrm{Na}$ & 0.643 & Sro & 0.0190 & $\mathrm{Sr}$ & 0.0168 \\
\hline $\mathrm{MgO}$ & 0.745 & $\mathrm{Mg}$ & 0.449 & $\mathrm{Nb}_{2} \mathrm{O}_{4}$ & 0.0077 & $\mathrm{Nb}$ & 0.0054 \\
\hline $2 \mathrm{nO}$ & 0.312 & $1 n$ & 0.251 & $\mathrm{CuO}$ & 0.0042 & $\mathrm{Cu}$ & 0.0034 \\
\hline Cl & 0.125 & Cl & 0.125 & $\mathrm{Ga}_{1} \mathrm{O}_{3}$ & 0.0028 & Ga & 0.0021 \\
\hline$p$ & 0.0052 & $\mathrm{P}$ & 0.0952 & & & & \\
\hline
\end{tabular}

\begin{tabular}{|l|l|}
\hline $\begin{array}{l}\text { Wave number } \\
\left(\mathrm{cm}^{+}\right)\end{array}$ & $\begin{array}{l}\text { Assignment } \\
\text { chemical groups }\end{array}$ \\
\hline $3600-3700$ & Bounded Water \\
\hline 3400 & Frec Water \\
\hline $1000-1100$ & lonic Plosphates \\
\hline 900 & lonic Carbonales \\
\hline $800-850$ & Silicon Carbide \\
\hline 700 & Si or P or S \\
\hline 550 & Conjugated Nitrite \\
\hline 550 & lonic Nitrite \\
\hline
\end{tabular}

\section{EXPERIMEN'TAL}

Ultra vioket spectra of tested crude oil (Sayed and Abu Baki, 2000) (Double beam UVSpectrophotometer, Shimadzu 160A) in $10 \mathrm{ml} \mathrm{n}$ hexane; at various concentrations, varied from 50 $\mu \mathrm{g} / \mathrm{ml}$ to $1200 \mu \mathrm{g} / \mathrm{ml}$. The mean peak occurs at wavelength range $285 \mathrm{~mm}-300 \mathrm{~mm}$.

A calibration curve of the tested crude oil in the Ultra violet range (Badr, ot al., 1988) in $10 \mathrm{ml} \mathrm{n}$ hexane; at various concentrations, varied from 50 $\mu \mathrm{g} / \mathrm{ml}$ to $1200 \mu \mathrm{g} / \mathrm{ml}$; by measuring absorbance values using $\mathrm{n}$-hexane as reference solution which obeys Bear's law up to $600 \mu \mathrm{g} / \mathrm{ml}$. Above $600 \mu \mathrm{g} / \mathrm{ml}$ there is a negative deviation due to the impurities incorporated within the tested crude oil and chemicals and reagents were of a guaranted grade used without further purification.

Then varied weights of the tested materials were contacted with agucous solutions $(25 \mathrm{ml})$ of different concentrations and constifuents for different times and temperatures in a Macarity tubes and shacked in a thermostatic water bath shaker. The phases were separated by centrifugation and then the oil was extracted in n-hexane and then determined by measuring the absorbance value.

The uptake efficiency of the petroleum crude oil on the different used materials was calcuhted according to the equation:

Uptake efficiency $\%=\left(\frac{W_{o}-W_{w}}{W_{o}}\right) \times 100$

Where, $W_{0}$ is the initial concentration and $W_{w}$ is the final concentration.
The adsorption isotherm in dilute solution was formulated by Freundlich (Kin 1998; Rene et al., 1993) as:

$$
C_{s}=K C_{w}^{\prime \prime}
$$

Where $C_{\text {s }}$ is the amount of oil retained by unit mass of adsorbent $C_{w}$ is the oil concentration and $K, n$ are constants

Another version of Freundlish is

$$
\mathrm{K}_{\mathrm{d}}=\mathrm{C}_{\mathrm{s}} / \mathrm{C}_{\mathrm{w}}
$$

Where the distribution ratio $\left(K_{4}\right)$ describes the portioning of the oil between adsorbent and liquid phases. Strongly adsorbed oil exhibits high $K_{d}$ values. The $K_{d}$ is also affected by pH, temperature, loading weight, and concentration of some cations and anious that are commonly present in water.

\section{RESULTS AND DISCUSSION}

The different parameters such as $\mathrm{pH}$, temperature, loading weight, concentration of some cations and anions that are commonly present in water and affect the employed materials sorption activity were studied.

a-SiO 2 quartz and sodium silicate: $\alpha-\mathrm{SiO}_{2}$ quartz and sodium silicate form the greatest clay composition percent as shown from X.R.D and X.R.F analyses of the Aswanly clay, so that, the effect of $\mathrm{pH}$ and loading weight on sorption of oil on their surfaces were studied (Sayed and Abu Bakr, 2002).

Effect of $p H$ : sorption process was studied by using an aqueous solution $(25 \mathrm{ml})$ covering all the $\mathrm{pH}$ range, containing $14.07 \mathrm{mg}$ oil, $0.1 \mathrm{~g}$ loading weight, at $15 \mathrm{~min}$ shaking time and at $30^{\circ} \mathrm{C}$. The relation between the uptake efficiency percent and solution 
$\mathrm{pH}$ is given in Fig. 2. It is clear that $\alpha-\mathrm{SiO}_{2}$ quartz and sodium silicate recorded high uptake effeciency percent at $\mathrm{pH} \leq 3$, where the surface is positively charged and at $\mathrm{pH} \geq 5 \alpha-\mathrm{SiO}_{2}$ quartz shows slight gradual increase in the uptake efficiency percent increase due to the formation of colloidal silica and formation of silicate (Duncan, 1992) as the $\mathrm{pH}$

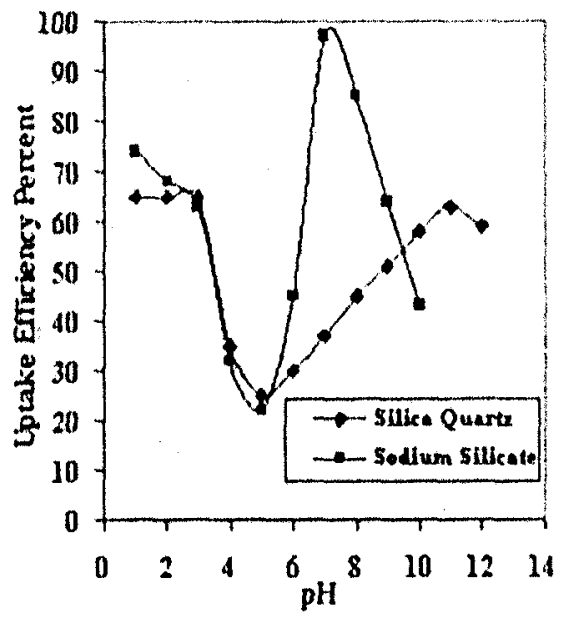

Iig. 2. Effect of pH on the uptake efficiency percent of oil-contaminated water on a - $\mathrm{SiO}_{2}$ Quartzand Sodium silicate

Effect of loading weight: The loading weight effect on sorption of oil contaminated water on the $\alpha-\mathrm{SiO}_{2}$ quartz and sodium silicate are studied by using an aqueous solution $(25 \mathrm{ml})$ of $\mathrm{pH} 6$, containing 14.07 $\mathrm{mg}$ oil, loading weight range $(0.1 \mathrm{~g}-1.5 \mathrm{~g}), 15 \mathrm{~min}$ shaking time at $30^{\circ} \mathrm{C}$. The effect of loading weight on the uptake efficiency percent of $a-\mathrm{SiO}_{2}$ quartz and sodium silicate to the oil is given in Fig. 3, which shows an increase of the uptake efficiency percent with increasing loading weight till it approaches a constant value at $1.1 \mathrm{~g}$ and $0.9 \mathrm{~g}$ for $\alpha-\mathrm{SiO}_{2}$ quartz and sodium silicate respectively. This is due to the increase of the adsorbing surface.

Incorporation of $\mathrm{Ca}, \mathrm{Mg}$ and $\mathrm{Ba}$ carbonates: $\mathrm{Ca}, \mathrm{Mg}$ and $\mathrm{Ba}$ carbonates are also incorporated within the clay. Sample solution $(25 \mathrm{ml})$, which contaminated with $17.04 \mathrm{mg}$ petroleum oil, shacked for 15 min shaking time and temperaturc $\left(30^{\circ} \mathrm{C}\right)$ are maintained as for the untreated Aswanly clay. While $\mathrm{pH}$ and loading weight effects are studied separately so, it is found previously (Ralph 1955) that it is the main determining factors affecting the uptake efficiency percent of the petroleum oil.

Effect of ph: The pH effect on sorption of oil contaminated water on the $\mathrm{Ca}, \mathrm{Mg}$ and $\mathrm{Ba}$ carbonates is studied using an aqueous solution $(25 \mathrm{ml})$ of $\mathrm{pH}$ range from 4 to 14 to minimize increases till it reaches a maximum value at pH 11 and then decreases slightly as they are sctlled down and also the same behavior is observed for sodium silicate which settles down over pll 7, while at $\mathrm{pH}$ range from 3 to 5 a lower uptake is observed because the sodium silicate surface is going to be neutrally charged

(Raiph

1955).

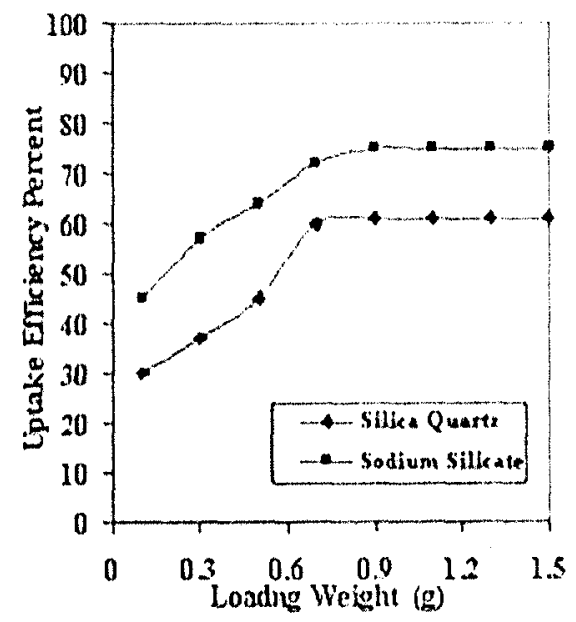

17ig. 3. leffect of loading weight on the uptake clficiency pereent of oil contaminated water on a $-\mathrm{SiO}_{2}$ Quartz and sodium sificate

carbonate solubility, that contains $14.07 \mathrm{mg}$ oil, $0.1 \mathrm{~g}$ loading weight, $15 \mathrm{~min}$ shaking time at $30^{\circ} \mathrm{C}$. The relation between the uptake efficiency percent and solution pH was given in Fig. 4. At pH range from 4 to 8 the uptake efficiency percent increases by increasing $\mathrm{pH}$ value where at pH range from 8-10.5 the uptake efficiency percent decreases by increasing pH. The uptake efficiency percent increases in the first region due to sorption on solid $\mathrm{CaCO}_{3}$ and decrease in the second region is due to solid $\mathrm{CaCO}_{3}$ solid and $\mathrm{Ca}(\mathrm{OH})_{2}$ equilibrium Vernon and David 1980) while, in the third region the gradual increase is due to $\mathrm{Ca}(\mathrm{OH})_{2}$ formed precipitate which, has a great surface to occlute the oil.

Effect of loading weight: The loading weight effect on sorption of oil contaminated water on the $\mathrm{Ca}, \mathrm{Mg}$ and $\mathrm{Ba}$ carbonates was studied using an aqueous solution $(25 \mathrm{ml})$ of $\mathrm{pH} 6$, containing $14.07 \mathrm{mg}$ oil, loading weight range $(0.01-0.13 \mathrm{~g}), 15 \mathrm{~min}$ shaking time, at $30^{\circ} \mathrm{C}$. The effect of loading weight on the uptake efficiency percent of the $\mathrm{Ca}, \mathrm{Mg}$ and $\mathrm{Ba}$ carbonates to the oil is given in Fig. 5; The highest values of uptake efficiency percents are 95, 100 and $95 \%$ at loading weight greater than $0.04,0.05$ and $0.08 \mathrm{~g}$ of $\mathrm{MgCO}_{3}, \mathrm{CaCO}_{3}, \mathrm{BaCO}_{3}$, respectively, i.e., as the weight of solid carbonates increases the uptake efficiency percent increases till it reaches a constant value because of the increase of surface area. 


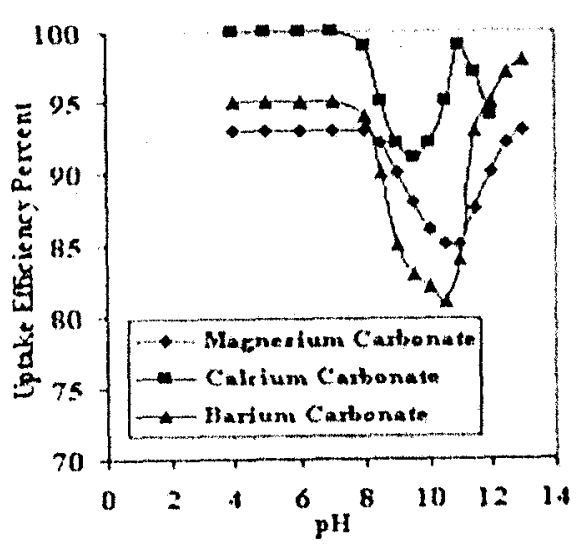

Fig. 4 . Effect of pll on the uptake efficiency percent of oil contaminated water on Maghesium, Calcium and Rarim Carbonates.

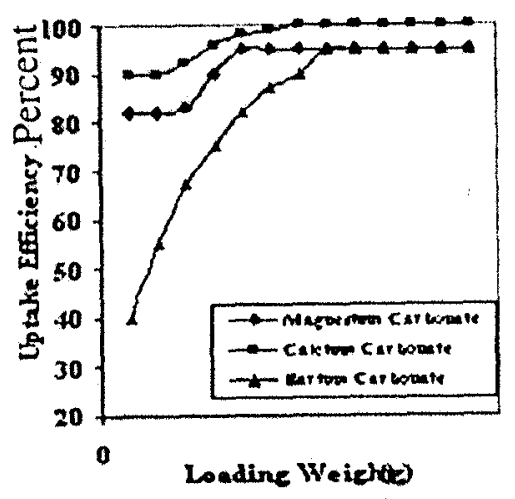

Fig. 5. Effect of loading weight on the uptake efficiency percent of oil conlaminated water on Magnesium, Calcium and Barium Carbonales.

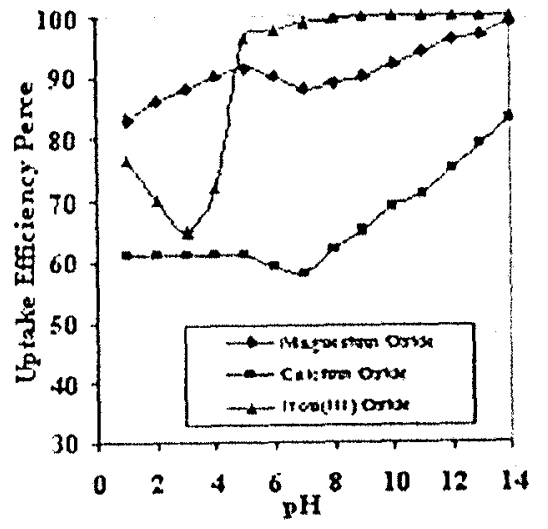

ligg. 6. Heffect of phl on the uptake efficiency pereent of oif contaninated water on Magnesiam, Calcium and Iron (III) Oxides

$\mathrm{Ca}, \mathrm{Mg}$ and Fe(III) oxides: $\mathrm{Ca}, \mathrm{Mg}$ and $\mathrm{Fe}(\mathrm{III})$ oxides are also incorporated in clay composition as shown from X.R.F analyses. The best conditions of sample volume $(25 \mathrm{ml})$, which is contaminated with $17.04 \mathrm{mg}$ petroleum oil, $15 \mathrm{~min}$ shaking time and temperature $\left(30^{\circ} \mathrm{C}\right)$ are maintained as for the untreated clay. While $\mathrm{pH}$ and loading weight effects are studied separately because.

Effect of pll: The pll effect on sorption of oil contaminated water on the $\mathrm{Ca}, \mathrm{Mg}$ and Fe(III) oxides

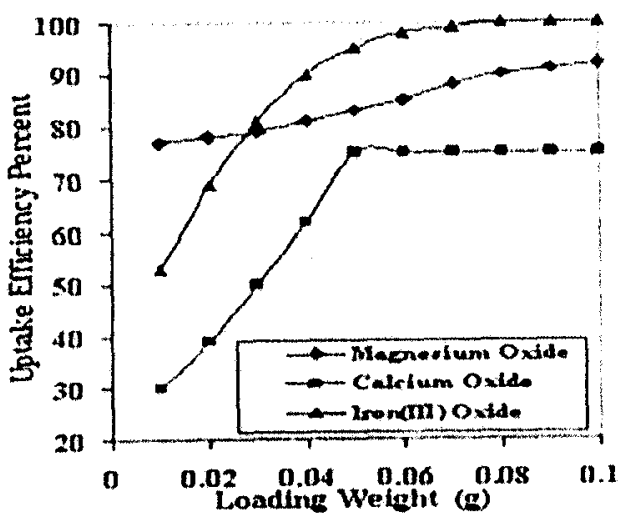

Fig. 7: Effect of loading weight on the tptake efficiency percent of oil contaminated water on Magnesium. Calcium and Barium Oxides.

was studied using an aqueous solution $(25 \mathrm{ml})$ of $\mathrm{pH}$ range from 1 to 14 , contains $14.07 \mathrm{mg}$ oil, $0.1 \mathrm{~g}$ loading weight, $15 \mathrm{~min}$ shaking time, at $30^{\circ} \mathrm{C}$. As shown in Fig. 6; in case of $\mathrm{Ca}$ and $\mathrm{Mg}$ oxides, a little increase is observed with $\mathrm{pH}$ increase because of the gradual formation of $\mathrm{Ca}$ and $\mathrm{Mg}$ hydroxides. While in case of $\mathrm{Fe}(\mathrm{III})$ oxide at $\mathrm{pH}$ lower than 5 , a decrease in the uptake efficiency percent is recorded with $\mathrm{Fe}(\mathrm{III})$ oxide dissolution and at pH which is greater than 5 the uptake efliciency percent increased due to the colloidal iron hydroxide formation (Duncan, 1992). 


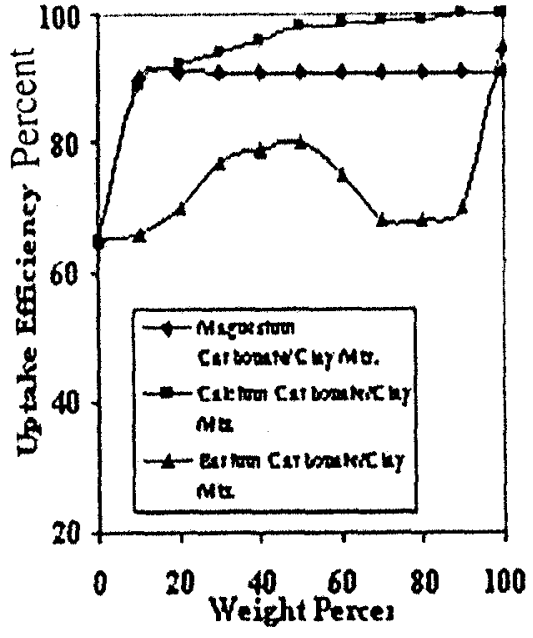

Fig. 8. Effect of weight percent on the uptake efficiency percent of oil contaminated water on Magnesium, Calcium and Barium Carbonates.

Effect of loading weight: The loading weight effect on sorption of oil contaminated water on the $\mathrm{Ca}, \mathrm{Mg}$ and $\mathrm{Fe}(\mathrm{III})$ oxides is studied using an aqueous solution $(25 \mathrm{ml})$ of pH 6 , contains $14.07 \mathrm{mg}$ oil, loading weight ranges from 0.01 to $0.1 \mathrm{~g}$, $15 \mathrm{~min}$ shaking time, at $30^{\circ} \mathrm{C}$. The effect of loading weight on the uptake efficiency percent of the $\mathrm{Ca}, \mathrm{Mg}$ and

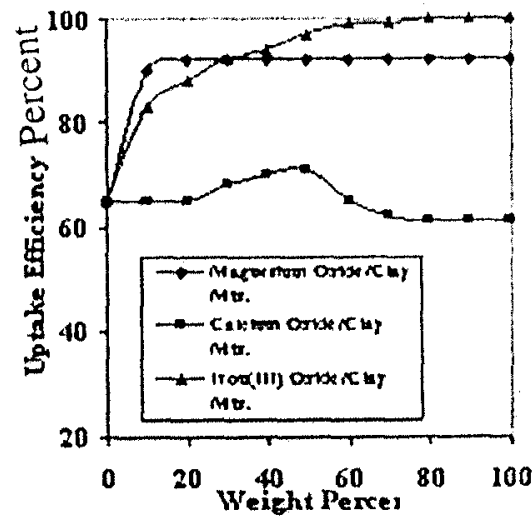

Fig. 9. Effect of weight percent on the uptake cfficiency percent of oil contiminated water on Magnesium. Calcium and Iron (III) Oxides.

Fe(III) oxides to the oil was given in Fig. 7; the highest values of uptake cfficiency percent 95, 100 and $95 \%$ are at loading weight greater than 0.04 , 0.05 and $0.08 \mathrm{~g}$ for $\mathrm{MgO}, \mathrm{CaO}$ and $\mathrm{Fe}_{2} \mathrm{O}_{3}$, respectively, i.c., as the weight of solid oxides increases the uptake efficiency percent increases till it reaches a constant value because of the increase of surface area.

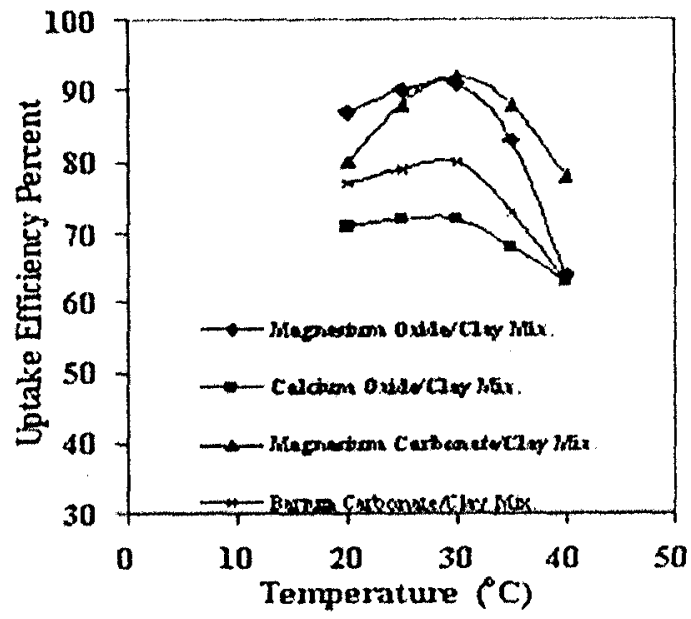

Fig. 10. Effect of Temperature on the uptake efficicncy percent of of contaminated water on Magnesium, Calcium Oxides and Magnesium, Barium Carbonates/Clay mixtures

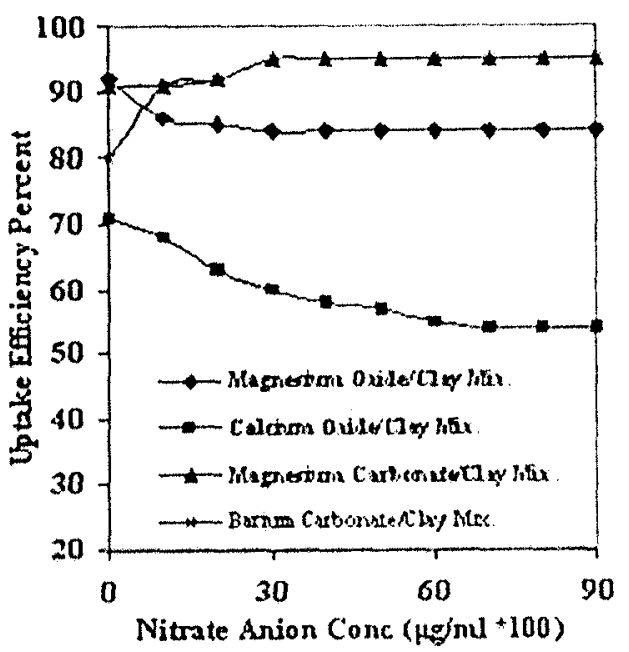

Fig. 11. Effect of Nitrate anion concentration on the uptake efficiency percett of oil comtaminated water on Magnesium. Calcium Oxides and Magnesium, Barium Cabonates/Clay mixlures. 


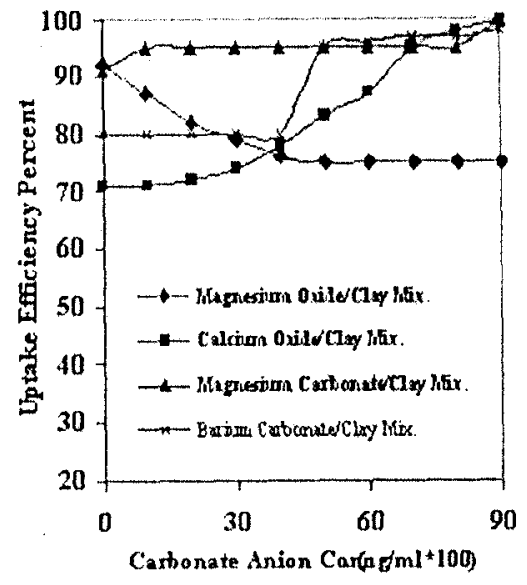

1.ig. 12. Hefice of Carbonate anion concentation on the uptake efficiency percent of oil contaminated water on Magnesium, Calcium Oxides and Magnesium, Barium Carbonates/Clay mixtures.

Uptake efficiency percem of metal carbonates or oxide/clay solid sorbents mixtures: An altempt to improve sorption process of petroleum oil on the untreated clay, some metal carbonates and oxides which show excellent uptake efficiency percent, as studied before, are added to the untreated clay to reduce the quantity of metal carbonates and oxides, hence costs and keeps using of untreated clay which shows good adsorption properties to heavy metals. The sorption effect of petroleum oil on solid $\mathrm{CaCO}_{3}$, $\mathrm{MgCO}_{3}, \mathrm{BaCO}_{3}, \mathrm{MgO}, \mathrm{CaO}, \mathrm{Fe}_{2} \mathrm{O}_{3} / \mathrm{Clay}$ mixures are studied by using a different continuous variation of solid metal oxide or carbonate / clay mixture

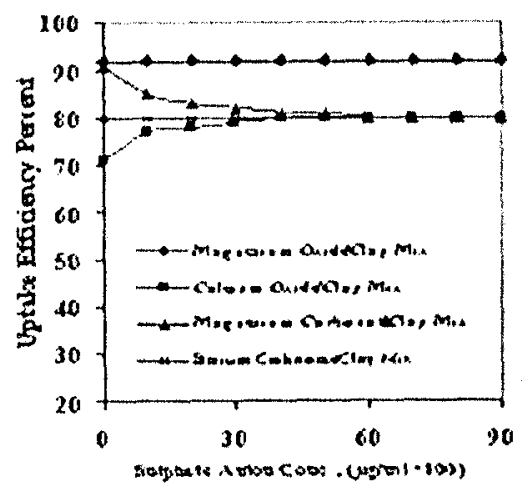

Fig. 14. Effect of Sulphate anion concentration on the uptake efficiency percent of oil contaminated water on Magnesium, Calcium Oxides and Magnesium, Barium Cabonates/Clay mixtures.

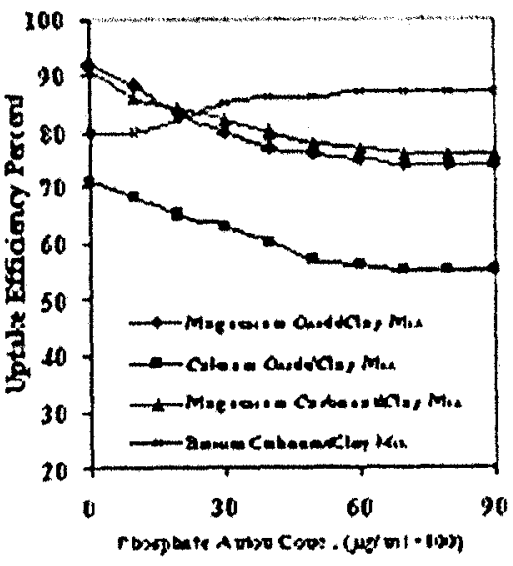

Fig. 13. Effect of Phosphate anion concentation on the uptake efficiency percent of oil comaminated water on Magnesium, Calcium Oxides and Magnesium, Barium Carbonates/Clay mixhures.

percents where the total weights was $0.1 \mathrm{~g}$. The study is conducled using an aqueous solution $(25 \mathrm{ml})$ of pll 6 , contains $14.07 \mathrm{mg}$ oil, $0.1 \mathrm{~g}$ londing weight, $15 \mathrm{~min}$ shaking time, at $30^{\circ} \mathrm{C}$. The relation between uptake efficiency percent and metal oxide or carbonate weight percent [(weigh of oxide or carbonate $\mathbf{0 . 1}$ ) $x^{*}$ 100] were shown in Figures 8 - 93. As shown in these figures, $10,50,40,10,40,50$ weight percents of $\mathrm{MgCO}_{3}, \mathrm{CaCO}_{3}, \mathrm{BaCO}_{3}, \mathrm{MgO}, \mathrm{CaO}, \mathrm{Fe}_{2} \mathrm{O}_{3}$ respectively are preferable to raise uptake efficiency percent of the untreated clay from $65 \%$ to $91,98,79$, $92, \quad 71$ and $97 \%$.

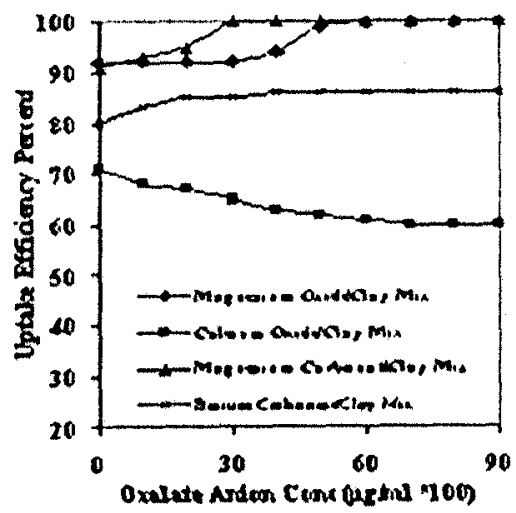

Fig. 15. Effect of Oxalate anion concentration on the uptake efficiency percent of oil contaminaled water on Magnesium, Calcium Oxides and Magnesium, Barium Carbonates/Clay mixtures. 


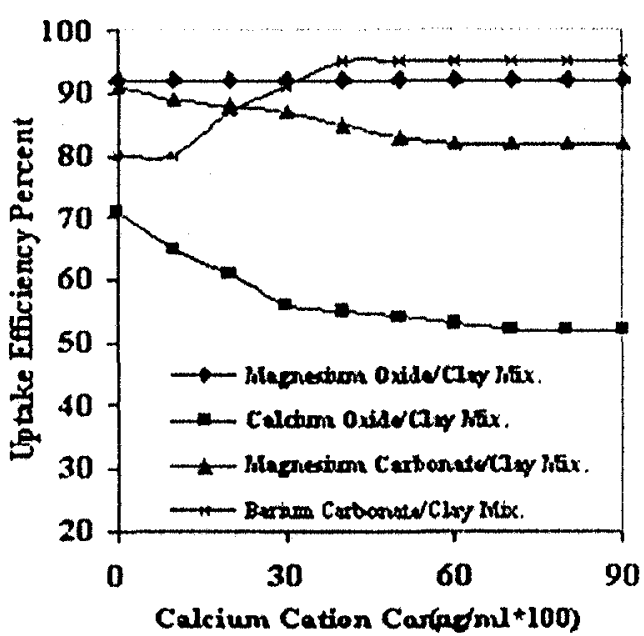

17ig. 16. Effect of Calcium cation concentration on the uptake efficicncy percent of oil contaminated water on Magnesium, Calcium Oxides and Magnesium, Barium Carbonates/Clay mixtures.

Some factors affecting the oil sorption process on some selected solid mixtures: Some factors affecting the oil sorption process on some selected solid mixtures $\mathrm{MgCO}_{3}, \mathrm{BaCO}_{3}, \mathrm{MgO}$ and $\mathrm{CaO} / \mathrm{Clay}$ mixtures are studied at the best conditions of the untreated clay using aqucous solution $(25 \mathrm{ml})$ of $\mathrm{pH}$ 6. contains $14.07 \mathrm{mg}$ oil, $0.1 \mathrm{~g}$ loading weight, 15 min shaking time, at different temperatures and at different anion and calcium cation concentrations.

Effect of temperature on some selected adsorbing mixtures: The temperature effect on sorption of oil contaminated water on the $\mathrm{MgCO}_{3}, \mathrm{BaCO}_{3}, \mathrm{MgO}$ and $\mathrm{CaO} / \mathrm{Clay}$ mixtures are studied using an aqueous solution $(25 \mathrm{ml})$ of pH 6 , contains $14.07 \mathrm{mg}$ oil, 0.1 g loading weight, $15 \mathrm{~min}$ shaking timc, temperature range from $20^{\circ} \mathrm{C}$ to $40^{\circ} \mathrm{C}$ and at optimum conditions of $10,50,10$ and $50 \%$ weight percents for $\mathrm{MgCO}_{3}$, $\mathrm{BaCO}_{3}, \mathrm{MgO}$ and $\mathrm{CaO} / \mathrm{Clay}$ mixtures. The effect of temperature on the uptake efficiency percent of the $\mathrm{MgCO}_{3}, \mathrm{BaCO}_{3}, \mathrm{MgO}$ and $\mathrm{CaO} / \mathrm{Clay}$ mixtures to the oil was given in Fig. 10; as the temperature increases the uptake efficiency percent increases till it reaches maximum at $30 \pm 3^{\circ} \mathrm{C}$ and after that decreases i.e., the sorption process is an endothermic process, while with temperature increase higher than $30^{\circ} \mathrm{C}$ the adsorbed oil tends to be less viscous and steadily leaves the solid sorbent/clay mixtures surface.

Effect of some anions on some selected adsorbing mixtures: The effect of some anions (nitratc, dihydrogenphosphate, bicarbonate, sulphate and oxalate) concentration on sorption of oil contaminated water on $\mathrm{MgCO}_{3}, \mathrm{BaCO}_{3}, \mathrm{MgO}$ and

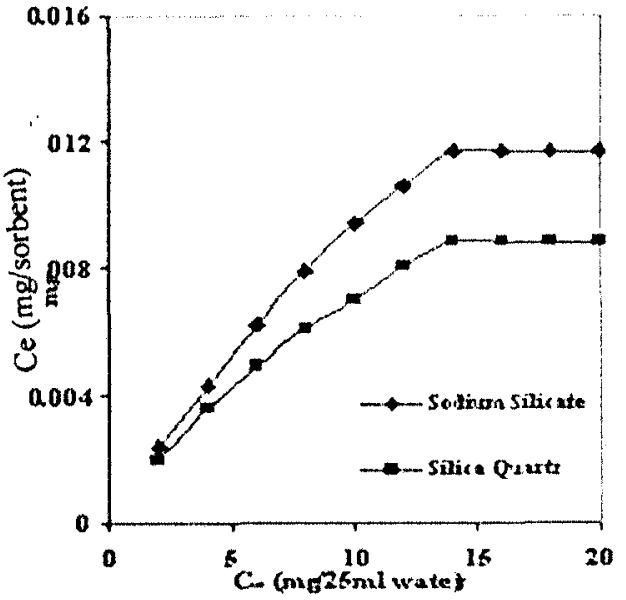

Fijg. 17. Distribution ratio $\left(K_{11}\right)$ between $u-S i O_{2}$ Quartz and Soxlium silicate sorbed phases and the aqueous phase.

$\mathrm{CaO} / \mathrm{Clay}$ mixtures are studied using an aqueous solution $(25 \mathrm{ml})$ of $\mathrm{pH} 6$, contains $14.07 \mathrm{mg} \mathrm{oil,} 0.1$ g loading weight, $15 \mathrm{~min}$ at $30^{\circ} \mathrm{C}$ and at optimum conditions of $10,50,10$ and $50 \%$ weight percents for $\mathrm{MgCO}_{3}, \mathrm{BaCO}_{3}, \mathrm{MgO}$ and $\mathrm{CaO} / \mathrm{Claly}$ mixtures, respectively. The relation between selected anion concentration and uptake cficiency pereent was given in Figures $11-15$. This may be attributed to the adsorption surface interaction between the clay and the solid added with a great influence of the anion free energies on the crystal structures of both the clay and the added solid. As shown in Figures, at the concentration of nitrate anions increases the uptake efficiency percent increases slightly in case of $\mathrm{MgCO}_{3}$ and $\mathrm{BaCO}_{3} / \mathrm{Clay}_{\text {mixtures }}$ till it reaches a constant value and decreases slightly till it reaches a constant value in case of $\mathrm{MgO}$ and $\mathrm{CaO} / \mathrm{Clay}$ mixtures. As the concentration of carbonate anions increases the uptake efficiency percent increases in case of $\mathrm{MgCO}_{3}, \mathrm{CaO}$ and $\mathrm{BaCO}_{3} /$ Clay mixtures till it reaches a constant value and decreases till it reaches a constant value in case of $\mathrm{MgO}$ /Clay mixture. As the concentration of phosphate anions increases the uplake efficiency percent increases in case of $\mathrm{BaCO}_{y}$ /Clay mixture till it reaches a constant value and decreases till it reaches a constant value in case of $\mathrm{MgCO}_{3}, \mathrm{CaO}$ and $\mathrm{MgO} / \mathrm{Clay}$ mixtures. With sulphate ions concentration the increase of the uptake efficiency percent of petroleum oil on $\mathrm{MgO}$ and $\mathrm{BaCO}_{3}$ /Clay mixtures has not any effect where the uptake efficiency percent of petroleum oil on $\mathrm{MgCO}_{3} / \mathrm{Clay}$ mixture increases and decreases in case of $\mathrm{CaO} / \mathrm{Clay}$ mixture. 


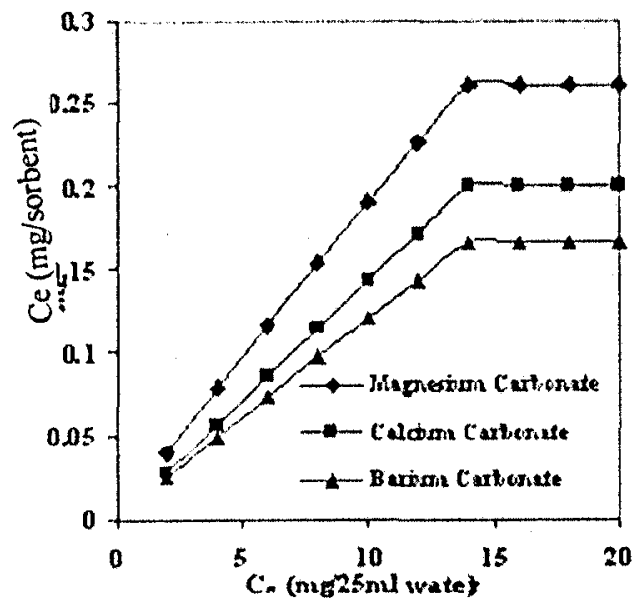

Fig. 18. Distribution ratio $\left(K_{s}\right)$ between Calcium, Magnesium and Barium Carbonates sorbed plases and the ayputous phase.

Effect of calcium (II) ion concentration on some selected adsorbing mixtures: The effect of calcium (II) ion concentration on sorption of oil contaminated water on the $\mathrm{MgCO}_{3}, \mathrm{BaCO}_{3}, \mathrm{MgO}$ and $\mathrm{CaO} / \mathrm{Clay}$ mixtures were studied using an aqueous solution $(25$ $\mathrm{ml}$ ) of pH 6 , contains $14.07 \mathrm{mg}$ oil, $0.1 \mathrm{~g}$ loading weight, $15 \mathrm{~min}$ shaking time, at $30^{\circ} \mathrm{C}$ and at optimum conditions of $10,50,10$ and $50 \%$ weight percents for $\mathrm{MgCO}_{3}, \mathrm{BaCO}_{3}, \mathrm{MgO}$ and $\mathrm{CaO} / \mathrm{Clay}$ mixtures. The relation between calcium ion concentration and uptake efliciency percent was given in Fig. 16; which may be attributed to the surface interaction between the clay and the solid added with a great influence of the anions free energies on the crystal structures of both clay and solid. As shown in Fig 16, as the concentration of calcium ion concentration increases the uptake efficiency percent increases slightly in

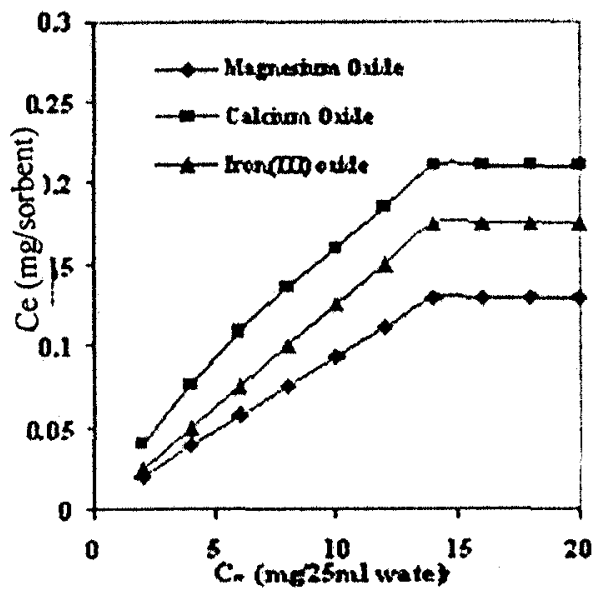

Fig. 19. Distribution ratio $\left(K_{4}\right)$ between Calcium, Magnesium and Iron (III) Oxides sorbed phases and the aqueous phase.

case $\mathrm{BaCO}_{y}$ Clay mixture till it reaches a constant value and decreases till it reaches a constant value in case of $\mathrm{MgCO}_{3}$ and $\mathrm{CaO} / \mathrm{Clay}$ mixtures and has not any effect in case of $\mathrm{MgO} / \mathrm{Clay}$ mixture. Finally, distribution ratio $\left(K_{d}\right)$ was calculated at optimum condition of $\mathrm{pH} 6$, temperature $30^{\circ} \mathrm{C}$, and loading weights $0.1 \mathrm{~g}$ for $1.0 \mathrm{~g}$ a $-\mathrm{SiO}_{2}$-Quartz, $0.9 \mathrm{~g}$ $\mathrm{Na}_{2} \mathrm{Si}_{2} \mathrm{O}_{5}(\mathrm{OH})_{4}, 0.07 \mathrm{~g} \mathrm{CaCO}_{3}, 0.05 \mathrm{~g} \mathrm{MgCO}_{3}, 0.08$ $\mathrm{g} \mathrm{BaCO}_{3}, 0.05 \mathrm{~g} \mathrm{CaO}, 0.1 \mathrm{~g} \mathrm{MgO}$, and $0.08 \mathrm{~g} \mathrm{Fe}_{2} \mathrm{O}_{3}$, $0.1 \mathrm{~g}$ clay mixture of $50 \% \mathrm{CaCO}_{3}, 0.1 \mathrm{~g}$ clay mixture of $10 \% \mathrm{MgCO}_{3}, 0.1 \mathrm{~g}$ clay mixture of $50 \% \mathrm{BaCO}_{3}$ $0.1 \mathrm{~g}$ clay mixure of $50 \% \mathrm{CaO}, 0.1 \mathrm{~g}$ clay mixture of $10 \% \mathrm{MgO}$, and $0.1 \mathrm{~g}$ clay mixture of $50 \% \mathrm{Fe}_{2} \mathrm{O}_{3}$. Distribution ratio $\left(K_{d}\right)$ was calculated by plotting $C_{s}$ versus $C_{w}$ as shown in Figures $17-21$, where, the slope of the resulting straight line is $K_{d}$ Values were calculated and presented in Table 4

Table 4: Distribution ratios $\left(K_{4}\right)$ between sorbed phases and aqueous phase

\begin{tabular}{|c|c|c|c|}
\hline Material & $K_{1}$ & Material & $K_{J}$ \\
\hline $\mathrm{SiO}_{2}$ & 0.0006 & $\mathrm{Fe}_{2} \mathrm{O}_{3}$ & 0.0125 \\
\hline $\mathrm{Na}_{2} \mathrm{Si}_{3} \mathrm{O}_{3}(\mathrm{OH})_{4}$ & 0.0008 & $\mathrm{MgCO}_{3} /$ Clay Mixture & 0.0088 \\
\hline $\mathrm{MgCO}$, & 0.0184 & $\mathrm{CaCO} / \mathrm{Clay}$ Mixure & 0.0098 \\
\hline $\mathrm{CaCO}_{1}$ & 0.0143 & $\mathrm{BaCO} / \mathrm{Clay}$ Mixture & 0.0125 \\
\hline $\mathrm{BaCO}_{3}$ & 0.0117 & $\mathrm{MgO}$ Clay Mixture & 0.0089 \\
\hline $\mathrm{MgO}$ & 0.0090 & $\mathrm{CaO} / \mathrm{Clay}$ Mixture & 0.0089 \\
\hline $\mathrm{CaO}$ & 0.0139 & $\mathrm{Fe}_{3} \mathrm{O}$ /Clay Mixture & 0.0097 \\
\hline
\end{tabular}




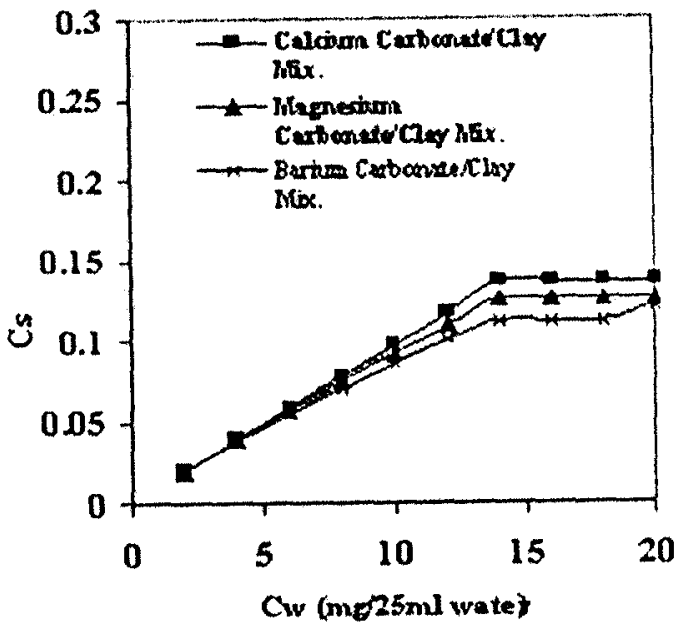

Fig. 20. Distribution ratio $\left(K_{1}\right)$ between Calcium, Magnesium and Barium Cabonates/Clay mixtures of $50 \%$ Calcium Carbonate, 10\% Magnesium Carbonale and 50\% Barium Carbonale sorbed phases and the aqueous plase.

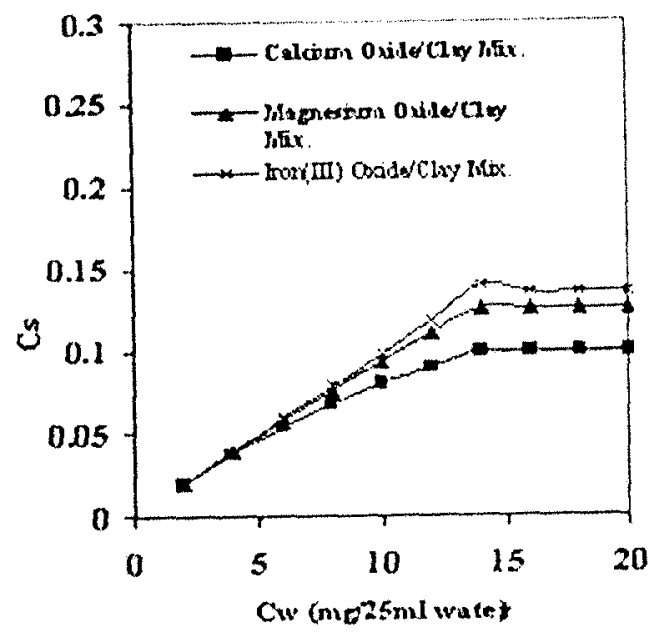

Fig. 21. Distribution ratio $\left(K_{d}\right)$ between Calcium, Magnesium and fron (Ili) Oxides/Clay mixtures of $50 \%$ Calcium Oxide, $10 \%$ Magnesium $0 x i d e$ and $50 \%$ fron (III) Oxide sorbed phases and the aqueous phase.
Since, strongly adsorbed oil exhibits high $K_{4}$ values. Sorbed phases according to values obtained in Table 4 can be arranged in the following order: $\mathrm{MgCO}_{3}>$ $\mathrm{CaCO}_{3}>\mathrm{CaO}>\mathrm{Fe}_{2} \mathrm{O}_{3}=\mathrm{BaCO}_{3} /$ Clay Mixlure $>$ $\mathrm{BaCO}_{3}>\mathrm{CaCO}_{3} /$ Clay Mixture $\approx \mathrm{Fe}_{2} \mathrm{O}_{3} /$ Clay Mixture $>\mathrm{MgO} \approx \mathrm{MgO}$ Clay Mixture $\approx \mathrm{CaO} /$ Clay Mixture $>$ $\mathrm{MgCO}_{3} /$ Clay Mixture $>\mathrm{Na}_{2} \mathrm{Si}_{2} \mathrm{O}_{5}(\mathrm{OH})_{4}>\mathrm{SiO}_{2}$.

\section{REFERENCES}

Abou El Naga, H H; Salem, A E; Youssel, H M S (1998) Testing local clays as active bleaching agents in regencration of used lubricating oils, $15^{\text {th }}$ International Conference on Chemical Education: Chemistry and Global Envirommental change, International Conference Charge, Egypt, vol. 1, pp. $117-134$.

Berridge, S A (1968) The properties of persistent oil at sea, Symposium on scientific aspects of pollution of the sea by oil, Institute of Petrolcum, $299-309$

Bo, G A (1987). Sorbent for oil or other liquid hydrocarbons", U.S. Patent 4,670,156

Bryk, M T; Yakovenkov, $N$ (1987). Magnetic adsorbent based on iron containing clay for removal of Petroleum from water, Sovict J. Chem. And Tech., 126-128, USSR,
Duncan, I S (1992). Introduction to colloid and surface chemistry, $4^{\text {th }}$ Edition, ButterworthHeinemann Lid., Great Britain,

Institute of Petrolcum (IP), 2001 Test Methods, Vol. 1,2 .

James R. Bragg and Shan H. Yang, 1996. Methods for forming mineral solids - oil floculles, U.S. Pitent 5,490,940,

Kin, $4 \mathrm{~T}(1998)$. Principles of soil chemistry $2^{\text {md }}$ Edition, Marcel Dekker Inc., U.S.A..

Latura, K (1961). Method and composition for clarifying wastewater", U.S. Patent 5, 670, 435, 1997.

Nelson - Smith, A. (1973). Oil pollution and marine ecology, First Edition, Plenum Press, New York, pp. 260 ,

Piwoni, M D; Banerjee, P (1989). Sorption of volatile organic solvents from aqueous solution onto subsurface solid. . J. Contam. Hydrol., 4, 163-179,.

Raiph, K I (1993). The colloid chemistry of silica and silicate, Ithaca, New York, 1955. 
Rene, P. S; Philip, M; Gschwnd, D M.I, (1993) Environmental organic chemistry", John Wiley and Sons, Inc., U.S.A.

Roy, M H, (1996). Pollution causes, effects and control, Third Edition, Royal Society of Chemistry, U.K.

Sayed, S A; Abu Bakr, M Z (2002). .A Study on Using Some Local clay in Treatment of Liquid Oil Spill, $1^{\text {st }}$ Int. Conf. On New Trends in Chemistry and Their Applications, Cairo Univ., Beni - Suef, Egypt, Feb. 2 -4, (Accepted for Publication).
Smith, H A (1980). The control of oil pollution, Graham and Trotman Lid. 66 Walton-road Swivide, 1983.

Wafaa, A A (1988) Application of some sinking agents for the treatment of oil spills", A Thesis Submitted For The degree of M.Sc., Cairo Univ., Egypt,.

Walliam, F; Morse, M E. (1979). Inorganic Materials Search Manual, Powder Diffraction File, JCPDS, Moscow.

Wauquier, J.P., 1995. Petroleum refining series", Vol. 1. Editions Technip, Paris, France. 